\title{
Lomefloxacin Induces Oxidative Stress and Apoptosis in COLO829 Melanoma Cells
}

\author{
Artur Beberok*, Dorota Wrześniok, Martyna Szlachta, Jakub Rok, Zuzanna Rzepka, \\ Michalina Respondek and Ewa Buszman \\ Department of Pharmaceutical Chemistry, School of Pharmacy with the Division of Laboratory Medicine, \\ Medical University of Silesia, Jagiellońska 4, 41-200 Sosnowiec, Poland; dwrzesniok@sum.edu.pl (D.W.); \\ szlachta.martyna@gmail.com (M.S.); jrok@sum.edu.pl (J.R.); zuzarzepka@gmail.com (Z.R.); \\ michalina.respondek@med.sum.edu.pl (M.R.); ebuszman@sum.edu.pl (E.B.) \\ * Correspondence: abeberok@sum.edu.pl; Tel./Fax: +48-32-364-1611
}

Received: 27 August 2017; Accepted: 16 October 2017; Published: 20 October 2017

\begin{abstract}
Although some fluoroquinolones have been found to exert anti-tumor activity, studies on the effect of these drugs on melanoma cells are relatively rare. The aim of this study was to examine the effect of lomefloxacin on cell viability, reactive oxygen species production, redox balance, cell cycle distribution, DNA fragmentation, and apoptosis in COLO829 melanoma cells. Lomefloxacin decreases the cell viability in a dose- and time-dependent manner. For COLO829 cells treated with the drug for 24,48 , and $72 \mathrm{~h}$, the values of IC50 were found to be $0.51,0.33$, and $0.25 \mathrm{mmol} / \mathrm{L}$, respectively. The analyzed drug also altered the redox signaling pathways, as shown by intracellular reactive oxygen species overproduction and endogeneous glutathione depletion. After lomefloxacin treatment, the cells were arrested in S- and G2/M-phase, suggesting a mechanism related to topoisomerase II inhibition. DNA fragmentation was observed when the cells were exposed to increasing lomefloxacin concentrations and a prolongation of incubation time. Moreover, it was demonstrated that the drug induced mitochondrial membrane breakdown as an early hallmark of apoptosis. The obtained results provide a strong molecular basis for the pharmacologic effect underlying the potential use of lomefloxacin as a valuable agent for the treatment of melanoma in vivo.
\end{abstract}

Keywords: lomefloxacin; melanoma; oxidative stress; DNA fragmentation; apoptosis

\section{Introduction}

Melanoma, the most deadly and aggressive form of skin cancer, derives from pigment-producing cells, namely, melanocytes [1]. These cells are characterized by pro-survival mechanisms that counteract damage-causing factors, including UV radiation [2]. The complex mechanisms of resisting cell death, already active in melanocytes, are further extended in melanoma cells, contributing to the melanoma pro-survival phenotype [1].

Throughout the years, the incidence of melanoma has continued to increase worldwide. According to the predictions of the American Cancer Society, about 90,000 new cases of melanoma will be diagnosed in 2017 [3]. Moreover, the statistics estimate a doubling of melanoma incidence every 10 to 20 years [4]. The prognosis for patients with advanced stages of cutaneous melanoma is poor, with a median survival time of less than one year [5] and a five year survival rate from 5 to $19 \%$ [4].

Until 2011, a chemotherapeutic alkylating agent, dacarbazine, was the standard drug for patients with metastatic melanoma, despite its modest efficacy and lack of documented survival benefit [6,7]. Recently, significant progress has been made towards melanoma treatment by approving monoclonal antibodies like ipilimumab, nivolumab, and prembrolizumab, as well as tyrosine kinases inhibitors like vemurafenib, dabrafenib, and trametinib [7-9]. However the persisting high toll of deaths resulting 
from melanoma, as well as a rapid increase in resistance to targeted drugs, is observed [6,7]. Therefore the search for novel chemotherapeutic agents for the treatment of melanoma is still needed.

Lomefloxacin belongs to fluoroquinolones, a class of synthetic antibiotics that are widely used for the treatment of various infections [10]. Their mechanism of bactericidal action involves the inhibition of type II isomerases, namely, DNA gyrase (topoisomerase II) and topoisomerase IV, which areprocaryotic enzymes that are functional analogs of eukaryotic topoisomerase II [11]. By selectively cleaving, rearranging, and religating double helixes, type II topoisomerases are able to relax supercoiled DNA and catalyze the decatenation of interlinked DNA molecules [12]. Fluoroquinolones form stable topoisomerase-drug-DNA complexes and inhibit helix religation. The occurrence of double-stranded DNA breaks disturbs replication and transcription processes, leading to cell death $[13,14]$.

Human topoisomerase II is well validated as a target for some classes of anti-cancer chemotherapeutic drugs, including anthracyclines (doxorubicin, epirubicin, daunorubicin, idarubicin, aclarubicin), mitoxantrone, epipodophyllotoxins (etoposide, teniposide), and amsacrine [15]. These agents act primarily by inhibiting the topoisomerase II-mediated religation of double-strand DNA breaks and thereby inducing apoptosis of cancer cells $[15,16]$. The clinical use of these antineoplastic drugs is limited by their sensitivity to P-glycoprotein-mediated efflux, as well as to high toxicity [11]. Therefore the search for novel human topoisomerase II inhibitors that avoid resistance due to P-glycoprotein expression is still reasonable.

Cancer cells exhibit higher levels of oxidative stress compared to normal cells. Disproportional increases in intracellular reactive oxygen species (ROS) may selectively induce cancer cell death either through random damaging functions of ROS or by the specific induction of apoptosis via the mitochondrial pathway $[17,18]$. Several in vitro $[19,20]$ and clinical $[21]$ studies have revealed that fluoroquinolones may cause the depletion of antioxidant enzyme activity and therefore induce significant disruption of the cellular antioxidant status.

Simultaneous topoisomerase II inhibition, apoptosis induction, and oxidative stress generation might be an effective strategy for inducing melanoma cell death. Therefore, we investigated, for the first time, the pro-apoptotic and pro-oxidant activity of lomefloxacin towards the melanotic COLO829 melanoma cell line.

The aim of this study was to examine the effect of lomefloxacin on cell viability, reactive oxygen species production, redox balance, cell cycle distribution, DNA fragmentation, and apoptosis in COLO829 melanoma cells. In order to provide strong experimental evidence for the use of lomefloxacin as a potential drug for the treatment of melanoma, the obtained results were compared with previously received data for normal human melanocytes [22].

\section{Results}

\subsection{Lomefloxacin Decreases the Viability of COLO829 Cells}

To evaluate the effect of lomefloxacin on the viability of human COLO829 melanoma cells, a WST-1 (4-[3-(4-iodophenyl)-2-(4-nitrophenyl)-2H-5-tetrazolio]-1,3-benzene disulphonate) assay was performed. As shown in Figure 1, the treatment of cells with lomefloxacin concentrations from 0.1 to $1.0 \mathrm{mmol} / \mathrm{L}$ for $24 \mathrm{~h}$ resulted in the decrease of cell viability by 12 to $68 \%$. The cytotoxic response was more marked after a prolongation of incubation time up to $48 \mathrm{~h}$ or $72 \mathrm{~h}$, wherein the viability of COLO829 cells treated with $0.1,0.5$, and $1.0 \mathrm{mmol} / \mathrm{L}$ lomefloxacin solutions decreased to $86 \%, 37 \%$, and $12 \%$ or $81 \%, 28 \%$, and $5 \%$, respectively. After the incubation of the cells with lower drug concentrations (from 0.0001 to $0.05 \mathrm{mmol} / \mathrm{L}$ ), the loss in cell viability was not statistically significant. For COLO829 cells treated with lomefloxacin for 24,48 , and $72 \mathrm{~h}$, the values of $\mathrm{IC}_{50}$ (the concentration of a drug that produces a loss in cell viability of $50 \%$ ) were found to be $0.51,0.33$, and $0.25 \mathrm{mmol} / \mathrm{L}$, respectively. 


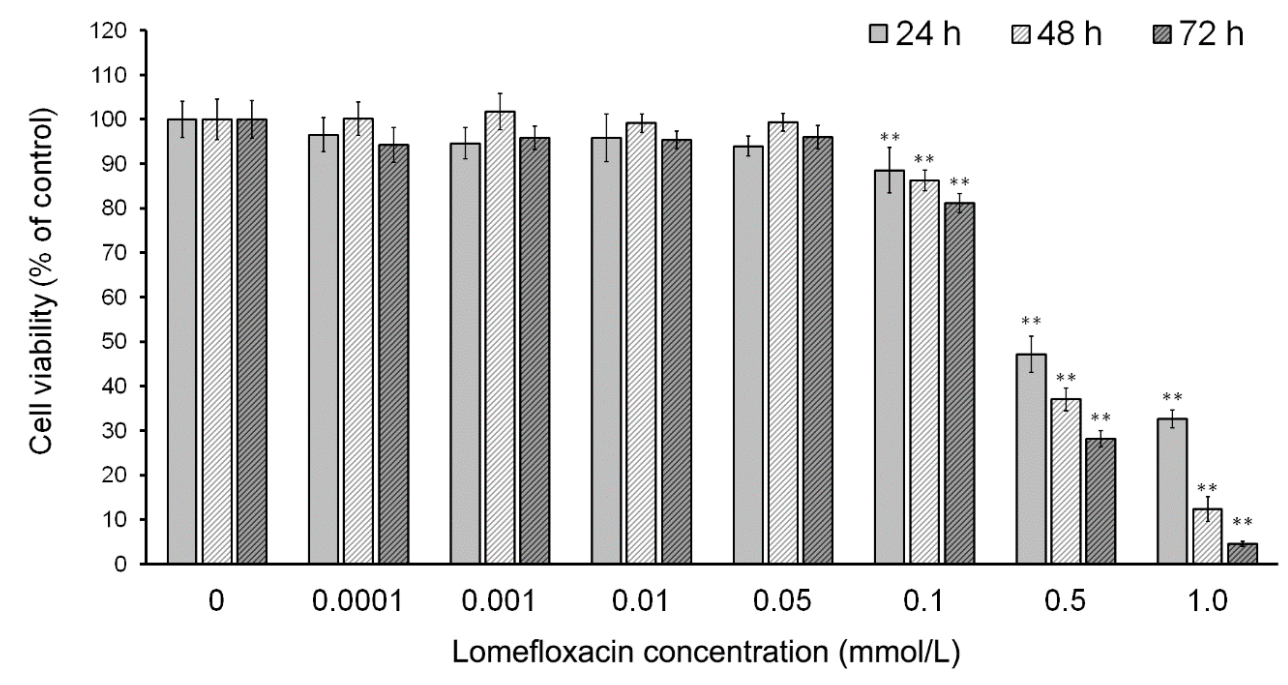

Figure 1. The effect of lomefloxacin on the viability of COLO829 melanoma cells. The cells were treated with various lomefloxacin concentrations $(0.0001-1.0 \mathrm{mmol} / \mathrm{L})$ for 24,48 , and $72 \mathrm{~h}$ and examined by the WST-1 (4-[3-(4-iodophenyl)-2-(4-nitrophenyl)-2H-5-tetrazolio]-1,3-benzene disulphonate) assay. Data are expressed as percentages of the controls. Mean values \pm standard error of the mean (SEM) from three independent experiments $(n=3)$ performed in triplicate are presented. ${ }^{* *} p<0.005$ versus control samples.

\subsection{Lomefloxacin Induces Morphological Changes in COLO829 Cells}

The morphology of COLO829 cells was estimated by the use of a light inverted microscope at $40 \times$ magnification. Figure 2 shows the morphological changes observed in COLO829 cells after incubation with lomefloxacin at a concentration of $1.0 \mathrm{mmol} / \mathrm{L}$ for 24,48 , and $72 \mathrm{~h}$. While the untreated cells (Figure 2A,C,E) grew adherently in culture flasks and had regular shapes and sizes, the cells treated with lomefloxacin at a concentration of $1.0 \mathrm{mmol} / \mathrm{L}$ for 24, 48, and $72 \mathrm{~h}$ (Figure 2B,D,F) became rounded and lost their regular shape and size. Moreover, a loss of cell to cell contact and a decrease in cell number was observed. After 48 and $72 \mathrm{~h}$ of incubation with lomefloxacin (Figure 2D,F), most of the COLO829 melanoma cells were detached from their substratum, displaying the typical morphological changes observed during the cell death process.
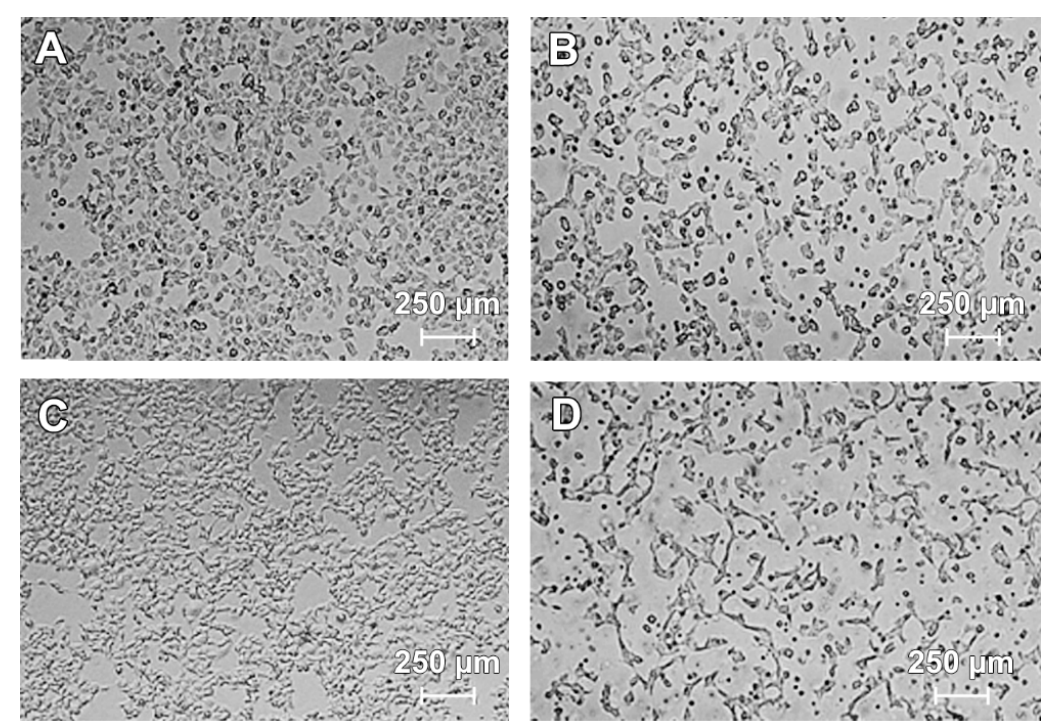

Figure 2. Cont. 

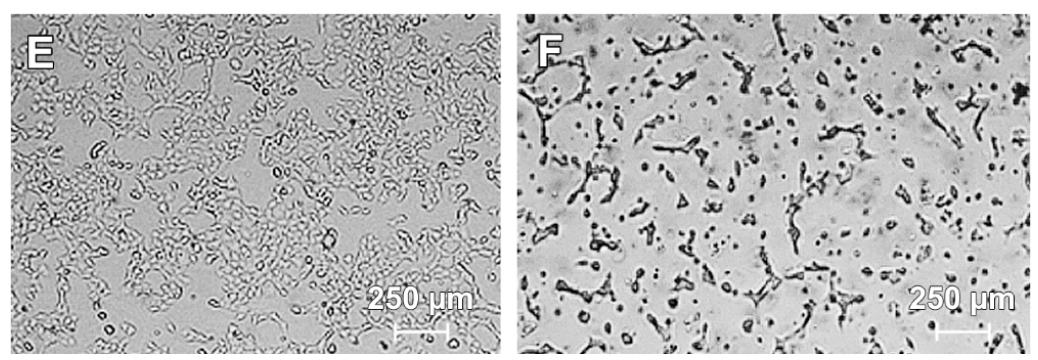

Figure 2. Lomefloxacin induces morphological changes in COLO829 melanoma cells: control COLO829 cells incubated for (A) $24 \mathrm{~h}$, (C) $48 \mathrm{~h}$, and (E) $72 \mathrm{~h}$; cells exposed to lomefloxacin at a concentration of $1.0 \mathrm{mmol} / \mathrm{L}$ for (B) $24 \mathrm{~h},(\mathbf{D}) 48 \mathrm{~h},(\mathbf{F})$ and $72 \mathrm{~h}$. The cells were observed under a light inverted microscope at $40 \times$ magnification (scale bar $250 \mu \mathrm{m}$ ).

\subsection{Lomefloxacin Induces ROS Generation in COLO829 Cells}

$\mathrm{H}_{2}$ DCFDA staining was used to detect ROS generation in COLO829 cells exposed to lomefloxacin treatment. As shown in Figure 3, the exposure of COLO829 cells to lomefloxacin leads to ROS overproduction in a concentration-dependent manner. The treatment of cells with lomefloxacin at concenrations $0.1,0.5$, and $1.0 \mathrm{mmol} / \mathrm{L}$ for $24 \mathrm{~h}$ enhanced ROS production by $38 \%, 93 \%$, and $137 \%$, respectively, in comparison to the untreated cells (controls).

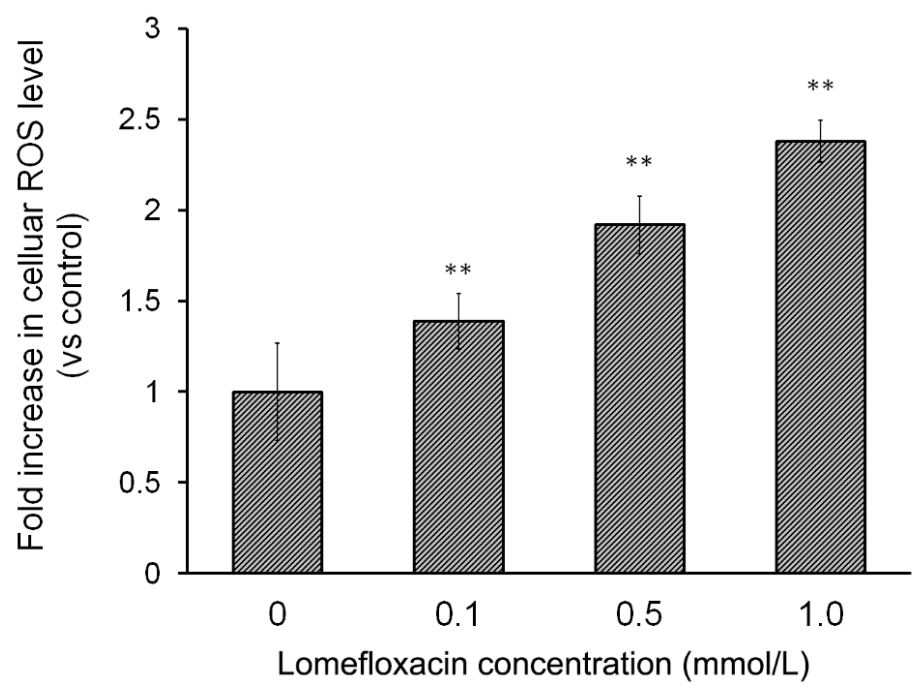

Figure 3. Lomefloxacin induces reactive oxygen species (ROS) production in COLO829 melanoma cells. The cells were exposed to the drug in concentrations of $0.1,0.5$, and $1.0 \mathrm{mmol} / \mathrm{L}$ for $24 \mathrm{~h}$. The data are expressed as percentages of the controls normalized to a number of living cells. Mean values \pm SEM from three independent experiments $(n=3)$ performed in triplicate are presented. ${ }^{* *} p<0.005$ versus control samples.

\subsection{Lomefloxacin Decreases the Level of Cellular Reduced Glutathione (GSH)}

A decrease in the cellular GSH level is an early sign of the progression of cell death in response to different pro-apoptotic agents. There is a strong correlation between cellular GSH depletion and the progression of apoptosis [23]. This phenomenon seems to be attributed mainly by direct GSH oxidation promoted by ROS. As shown in Figure 4, lomefloxacin caused a cellular decrease in the level of glutathione in its reduced state. Following image cytometric analyses after the exposure of COLO829 cells to lomefloxacin in concentrations of 0.1 and $1.0 \mathrm{mmol} / \mathrm{L}$ for $24 \mathrm{~h}$, the percentage of PI (propidium iodide) negative cells with low vitality (with reduced GSH levels) increased from 5 to 11 and 13\%, respectively. The response was more marked after the prolongation of the incubation time up to 
$48 \mathrm{~h}$; for lomefloxacin at a concentration of $0.1 \mathrm{mmol} / \mathrm{L}$, the percentage of cells with reduced GSH levels increased from 7 to $42 \%$. Simultaneously, the treatment of COLO829 cells with lomefloxacin in concentrations of 0.1 and $1.0 \mathrm{mmol} / \mathrm{L}$ for 24 and $48 \mathrm{~h}$ increased the percentage of PI positive cells (dead cells) from 6 to $31 \%$ and from 3 to $28 \%$, respectively.

A. Control

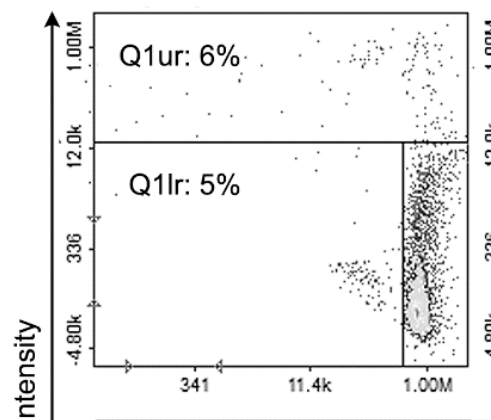

$\frac{1}{a}$

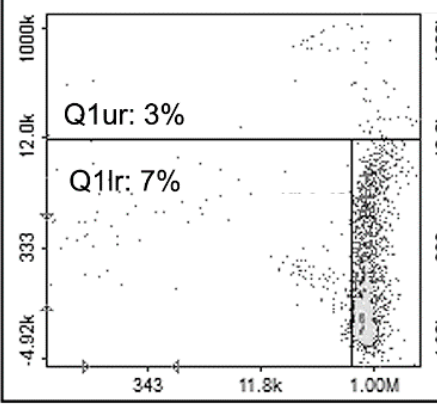

Lomefloxacin $0.1 \mathrm{mmol} / \mathrm{L}$
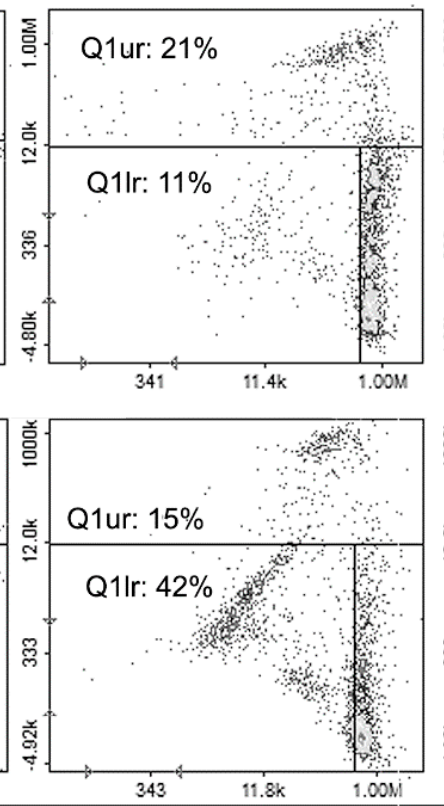

VB48 - Intensity

B.

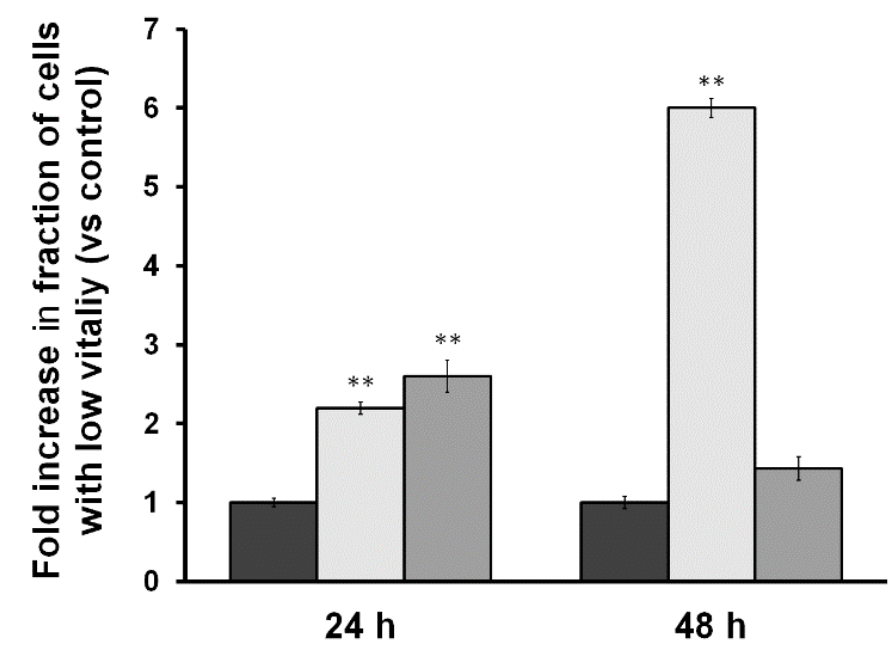

\section{Lomefloxacin} $1.0 \mathrm{mmol} / \mathrm{L}$

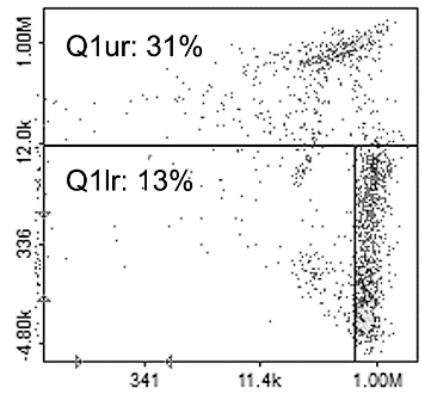

$24 \mathrm{~h}$

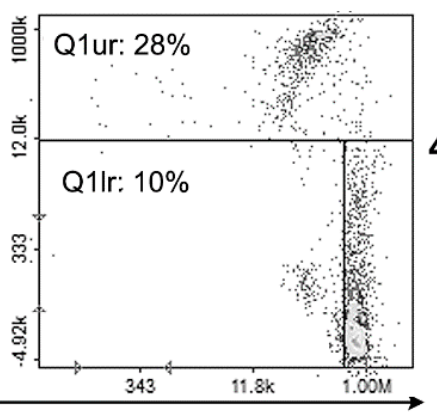

$48 \mathrm{~h}$

Figure 4. Analysis of the cellular Cellular Reduced Glutathione (GSH) levels in COLO829 cells after exposure to lomefloxacin treatment. (A) Histograms presenting the changes of GSH levels in cells exposed to lomefloxacin in concentrations of 0.1 and $1.0 \mathrm{mmol} / \mathrm{L}$. The presented histograms are representative of three independent experiments with similar results. Q1ur are dead cells; Q11r are cells with low GSH levels (with low vitality). (B) The effect of lomefloxacin on cellular GSH levels in COLO829 cells. The cells were treated with lomefloxacin in concentrations of 0.1 and $1.0 \mathrm{mmol} / \mathrm{L}$ for 24 and $48 \mathrm{~h}$. Mean values \pm SEM from three independent experiments $(n=3)$ performed in triplicate are presented. ${ }^{* *} p<0.005$ versus control samples. 


\subsection{Lomefloxacin Induces $S$ and $G_{2} / M$-Phase Arrest and DNA Fragmentation in COLO829 Cells}

To examine the possible mechanism underlying the cytotoxic activity of lomefloxacin towards COLO829 melanoma cells, the cell cycle changes were estimated using a fluorescence image cytometer. The cells were distributed among three major phases of the cell cycle: $G_{1} / G_{0}$ phase (one set of paired chromosomes per cell), S-phase (DNA synthesis with a variable amount of DNA), and $\mathrm{G}_{2} / \mathrm{M}$ phase (two sets of paired chromosomes per cell, prior to cell division). The treatment of COLO829 cells with lomefloxacin at a concentration of $1.0 \mathrm{mmol} / \mathrm{L}$ for 24 and $48 \mathrm{~h}$ induced significant $\mathrm{G}_{2} / \mathrm{M}$ phase arrest (Figure 5), with the percentages of $\mathrm{G}_{2} / \mathrm{M}$ fraction increasing from 23 to $31 \%$ and from 24 to $36 \%$, respectively. Simultaneously, lomefloxacin in the chosen exposure conditions caused a significant increase in the S-phase peak from 14 to $23 \%$ and from 11 to $16 \%$, respectively. Moreover, following the image cytometric analyses (Figure 6), lomefloxacin was found to induce DNA fragmentation, the late event in the apoptosis pathway in COLO829 melanoma cells. This phenomenon was demonstrated only for lomefloxacin at concentrations of 0.1 and $1.0 \mathrm{mmol} / \mathrm{L}$ and after $48 \mathrm{~h}$ of incubation, when the percentages of cells in the sub- $\mathrm{G}_{1}$ phase (having less than one DNA equivalent) increased from 6 to $22 \%$ and from 6 to $38 \%$, respectively.

a
A
A
$\mid$
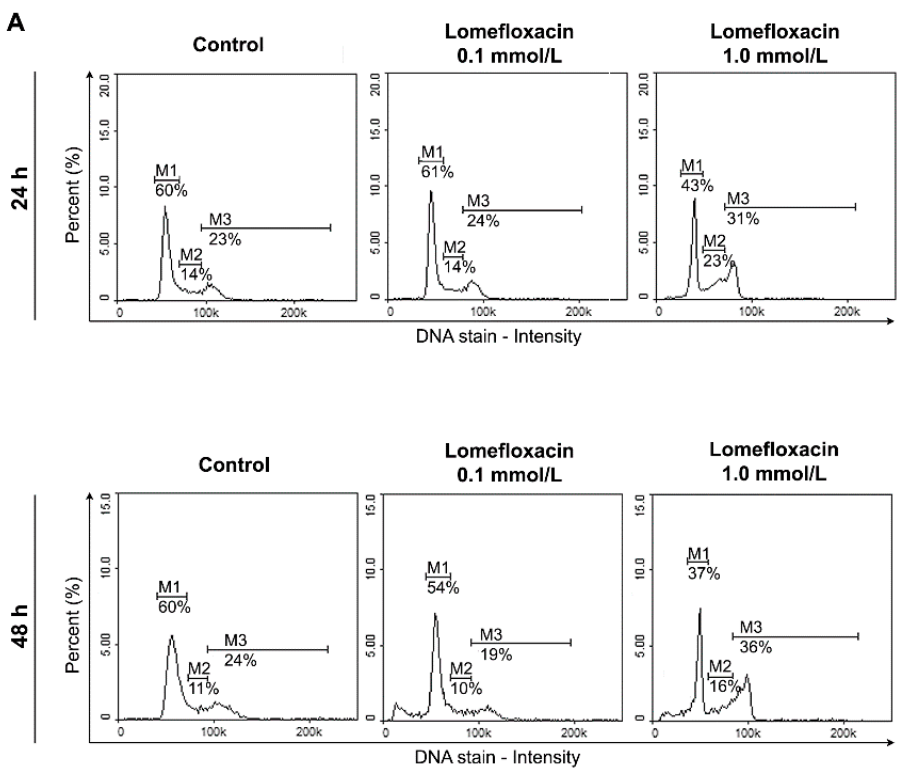

B
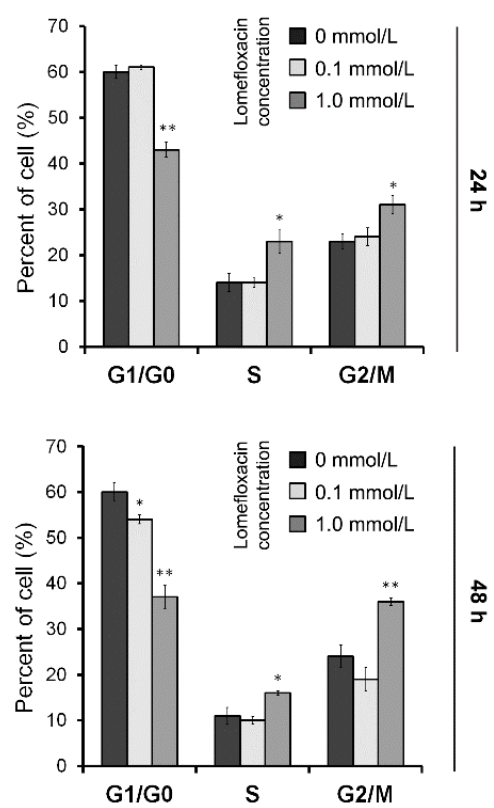

Figure 5. Cell cycle analysis of COLO829 cells exposed to lomefloxacin. (A) Histograms presenting the cell cycle distribution in cells exposed to lomefloxacin in concentrations of 0.1 and $1.0 \mathrm{mmol} / \mathrm{L}$ for 24 and $48 \mathrm{~h}$. The presented histograms are representative of three independent experiments with similar results. The effect of the drug on the cell cycle distribution was investigated by a fluorescence image cytometer after DAPI (4',6-diamidino-2-phenylindole) staining. $\mathrm{M}_{1} \mathrm{G}_{1} / \mathrm{G}_{0}$ phase; $\mathrm{M} 2-\mathrm{S}$-phase; M3 $-\mathrm{G}_{2} / \mathrm{M}$ phase. (B) The effect of lomefloxacin on the cell cycle distribution in COLO829 cells. The cells were treated with lomefloxacin at concentrations of 0.1 and $1.0 \mathrm{mmol} / \mathrm{L}$ for 24 and $48 \mathrm{~h}$. Mean values \pm SEM from three independent experiments $(n=3)$ performed in triplicate are presented. ${ }^{*} p<0.05$ versus control samples; ${ }^{* *} p<0.005$ versus control samples. 

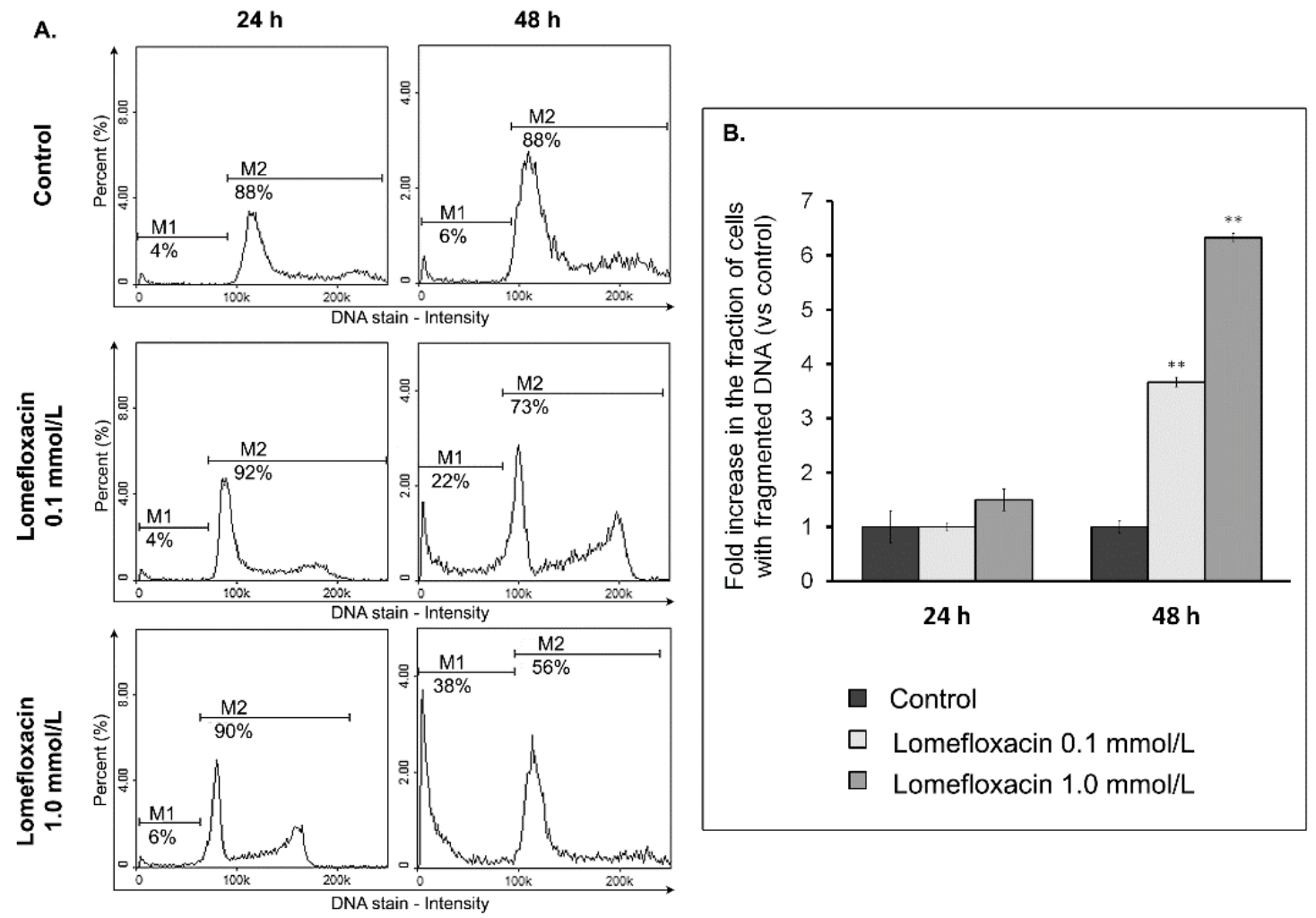

Figure 6. Lomefloxacin induces DNA fragmentation in COLO829 melanoma cells. (A) Histograms presenting the induction of DNA fragmentation in cells exposed to lomefloxacin at concentrations of 0.1 and $1.0 \mathrm{mmol} / \mathrm{L}$ for 24 and $48 \mathrm{~h}$. The presented histograms are representative of three independent experiments with similar results. The effect of the drug on DNA fragmentation was investigated by a fluorescence image cytometer after DAPI staining. M1—cells having less than one DNA equivalent (so-called sub-G 1 cells); M2 - cells having one or more than one DNA equivalent. (B) The effect of lomefloxacin on DNA fragmentation in COLO829 cells. The cells were treated with lomefloxacin at concentrations of 0.1 and $1.0 \mathrm{mmol} / \mathrm{L}$ for 24 and $48 \mathrm{~h}$. Mean values \pm SEM from three independent experiments $(n=3)$ performed in triplicate are presented. ${ }^{* *} p<0.005$ versus control samples.

2.6. Lomefloxacin Disrupts Mitochondrial Transmembrane Potential in COLO829 Cells and Increases the Level of Late-Apoptotic Cells

A variety of key events during apoptosis involve the mitochondria. Hence, to confirm the involvement of mitochondria in lomefloxacin mediated apoptotic cell death, the mitochondrial membrane potential in lomefloxacin treated COLO829 melanoma cells was estimated. The mitochondrial membrane potential is a crucial parameter of mitochondria function that is used as an indicator of cell death. JC-1 is a lipophilic, cationic dye that can selectively enter mitochondria and reversibly change their color from green to red with increasing membrane potential. In healthy cells with high levels of mitochondria, JC-1 forms complexes with intense red fluorescence, while, in apoptotic cells with low mitochondrial membrane potential, JC-1 remains in the monomeric form, which shows green fluorescence. Following image cytometric analyses (Figures 7 and 8), the percentages of mitochondrial membrane depolarized cells increased only when COLO829 melanoma cells were exposed to lomefloxacin at a concentration of $1.0 \mathrm{mmol} / \mathrm{L}$ for $24 \mathrm{~h}$ (which increased by $10 \%$ compared to the controls). There was no increase in the percentage of depolarized COLO829 cells after the prolongation of incubation time up to $48 \mathrm{~h}$ and $72 \mathrm{~h}$. Simultaneously, a significant increase in blue DAPI (4',6-diamidino-2-phenylindole) fluorescence (Figure 7) was observed, indicating the induction of late-apoptosis after the exposure of COLO829 cells to increasing drug concentrations and the prolongation of the incubation time. The late-apoptotic cell percentages for lomefloxacin treated cells in concentrations of 0.1 and $1.0 \mathrm{mmol} / \mathrm{L}$ were $12 \%$ and $16 \%$ 
for $24 \mathrm{~h}$ of incubation, $13 \%$ and $24 \%$ for $48 \mathrm{~h}$ of incubation, and $6 \%$ and $46 \%$ for $72 \mathrm{~h}$ of incubation, while the values determined for the controls were $8 \%, 10 \%$, and $7 \%$, respectively.

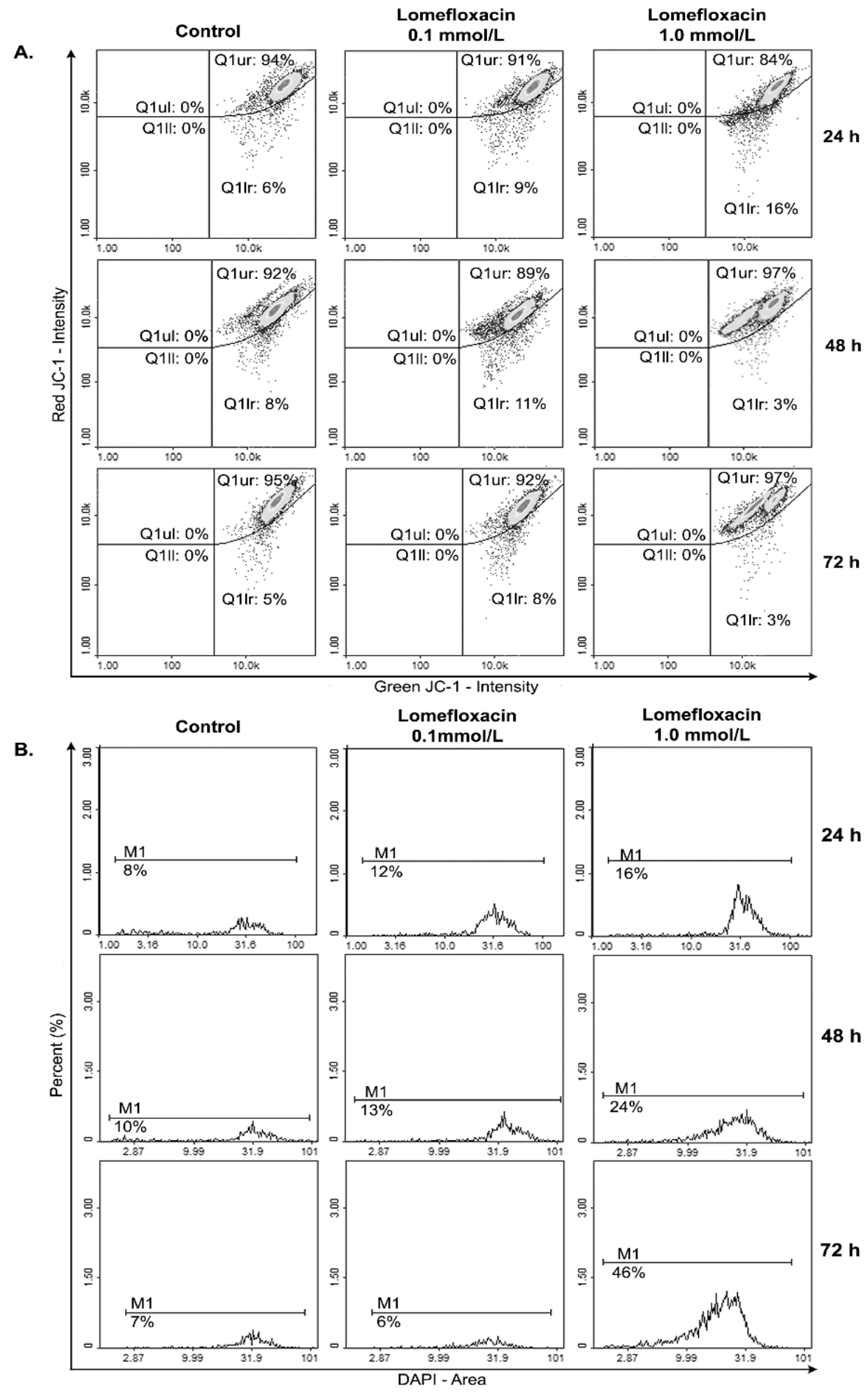

Figure 7. Lomefloxacin induces apoptosis in the COLO829 melanoma cell line. The cells treated with lomefloxacin in concentrations of 0.1 and $1.0 \mathrm{mmol} / \mathrm{L}$ for 24,48 , and $72 \mathrm{~h}$ were stained with (A) JC-1 and (B) DAPI dyes and analyzed by a fluorescence image cytometer. The presented histograms are representative of three independent experiments with similar results. 


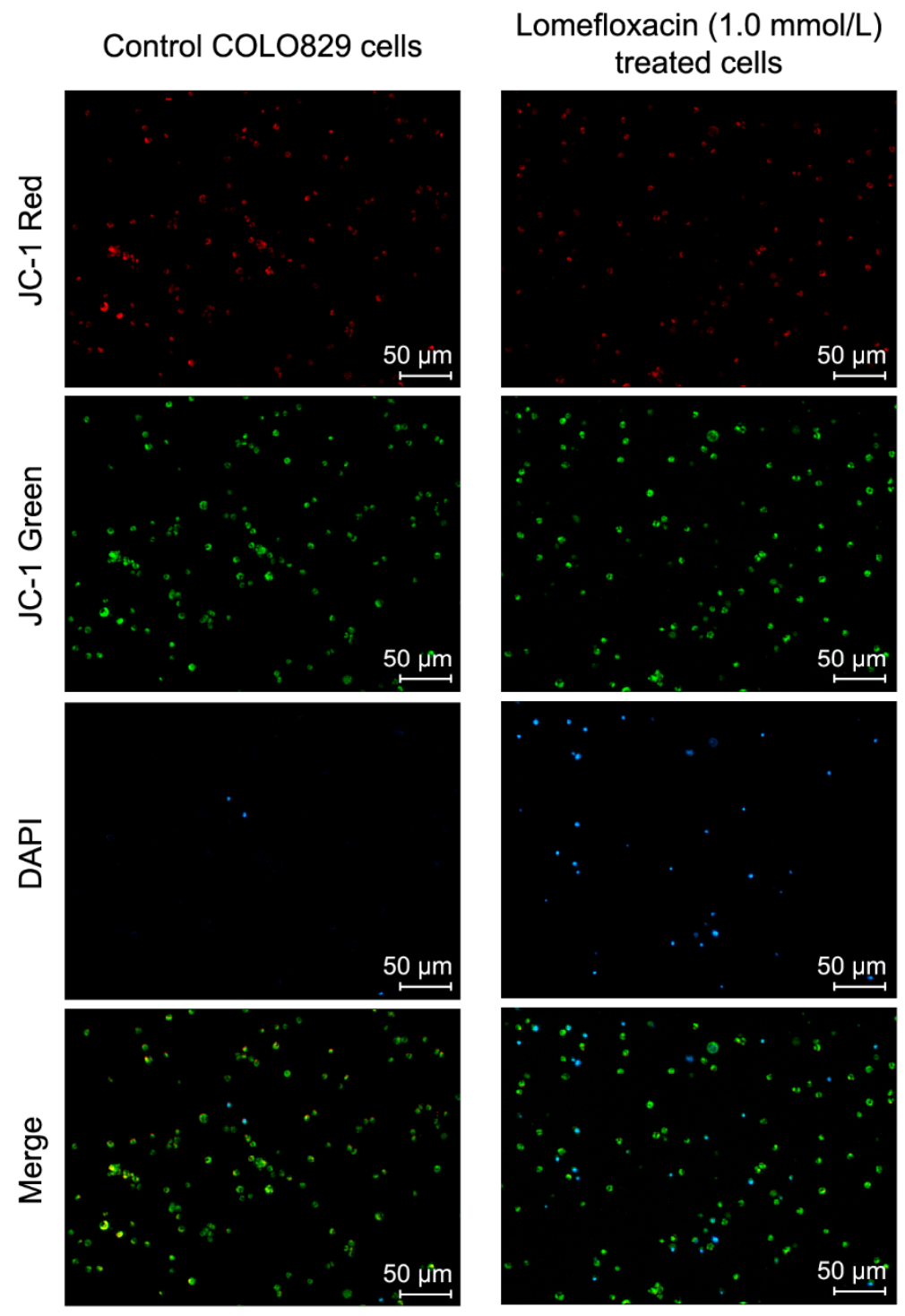

Figure 8. Lomefloxacin induces changes in cellular red and green (JC-1) or blue (DAPI) fluorescence intensity as a result of apoptosis induction in COLO829 cells. The cells were treated with lomefloxacin at a concentration of $1.0 \mathrm{mmol} / \mathrm{L}$ for $24 \mathrm{~h}$. The cells were observed under a fluorescence image cytometer (scale bar $50 \mu \mathrm{m}$ ). Q1ur-mitochondrial membrane polarized cells; Q1lr-mitochondrial membrane depolarized/apoptotic cells; M1-DAPI-positive/late apoptotic cells.

\section{Discussion}

Despite the recent progress in melanoma therapies, many metastatic melanoma patients still demonstrate a high mortality risk. The aggressive nature of this type of cancer, the occurrence of drug resistance, and severe side effects associated with currently used therapies are the cause of an urgent need for effective anti-melanoma agents [24].

Fluoroquinolone derivatives display activity, not only against bacterial topoisomerases, but also against eukaryotic topoisomerases and thus exert toxicity to mammalian cancer cell lines and in vivo tumor models [25]. The novel quinolone-based topoisomerase II inhibitor, called Vosaroxin (syn. Voreloxin), is under phase III clinical trials to treat the patients with acute myelogenous leukemia and ovarian cancer $[11,26]$. Nevertheless, several in vitro studies have shown that well known fluoroquinolone derivatives like ciprofloxacin, levofloxacin, enoxacin, ofloxacin, fleroxacin, moxifloxacin, and gatifloxacin induce apoptosis and cell cycle arrest in various cancer cell lines, 
e.g., bladder carcinoma, transitional carcinoma, and colon carcinoma cells [27-30]. Fluoroquinolone antibiotics may thus be considered an exploitable source of potent anticancer drugs with already established pharmacokinetic characteristics, which makes them unique among other classes of antibiotic members.

Previously we have demonstrated that lomefloxacin [31], in comparison to other fluoroquinolone derivatives like norfloxacin and moxifloxacin [20], possesses the highest capacity to induce oxidative stress in normal human melanocytes. The depletion of antioxidant status was demonstrated by the ability of the drug to alter the activity of the cellular antioxidant enzymes superoxide dismutase (SOD), catalase (CAT), and glutathione peroxidase (GPx), which indicates that lomefloxacin triggers the generation of ROS, mainly superoxide radical anion and hydrogen peroxide. This phenomenon may be explained by the nature and position of the substituents attached to the quinolone ring [32]. Halogenation (chlorine, fluorine) of position 8, in concert with fluorination of position 6 (the so-called double-halogenated quinolones), has demonstrated a strong ability to produce ROS. Therefore, lomefloxacin and sparfloxacin have been reported to have relatively high toxic potential compared with other fluoroquinolones, e.g., ciprofloxacin or norfloxacin [33].

On the basis of limited in vitro and in vivo data documenting the potential cytotoxic effect of lomefloxacin, and because the molecular mechanism underlying the anticancer action of this drug is not elucidated, we investigated the effect of lomefloxacin on the human melanoma cell line. In this study, we determined for the first time the impact of the drug on cell viability, ROS generation, the level of GSH, cell cycle distribution, and the apoptosis pathway in human melanotic COLO829 melanoma cells.

Lomefloxacin was found to decrease the viability of COLO829 melanoma cells in a time- and concentration-dependent manner (Figure 1). After the incubation of cells with lomefloxacin for $24 \mathrm{~h}$, a decrease in cell viability was observed for higher drug concentrations (from 0.1 to $1.0 \mathrm{mmol} / \mathrm{L}$ ) up to $32 \%$ of the control. The cytotoxic response was more marked when the cells were incubated with lomefloxacin for 48 and $72 \mathrm{~h}$. At these conditions, the drug at the highest analyzed concentration $(1.0 \mathrm{mmol} / \mathrm{L})$ decreased the viability of COLO 829 cells by $88 \%$ and $95 \%$, respectively. The cell morphology assessment indicated that cells treated with lomefloxacin became rounded and lost their cell-cell contact (Figure 2). Moreover, cell shrinkage, reduced cell volume, and irregularities in cell contour and size, which are all well known apoptotic characteristics, were noticed. The observed changes in cell morphology were found to be irreversible, suggesting that the cells were programmed to die when treated with lomefloxacin. Perucca et al. [34] analyzed the cytotoxic effect of lomefloxacin in the epithelial cancer cell lines human cervix carcinoma (HeLaS3) and squamous carcinoma (A431). The authors demonstrated that lomefloxacin in the highest analyzed concentration $(0.1 \mathrm{mmol} / \mathrm{L})$ reduced the number of A431 cells by about $30 \%$ after $24 \mathrm{~h}$ incubation. Simultaneously, this drug had no effect on the viability of HeLaS3 cells, which indicates that lomefloxacin is similar and more cytotoxic to A431 and HeLaS3 epithelial cancer cells. Previously we have demonstrated that the treatment of normal human epidermal melanocytes with lomefloxacin for $24 \mathrm{~h}$ decreased the cell viability in a concentration-dependent manner [22]. The exposure of cells to lomefloxacin in concentrations from 0.1 to $1.0 \mathrm{mmol} / \mathrm{L}$ decreased the cell viability by 17 to $74 \%$. The main difference between the cytotoxicity of lomefloxacin towards COLO829 melanoma cells and towards normal human melanocytes was observed when the $\mathrm{IC}_{50}$ values were compared. The value of $\mathrm{IC}_{50}$ determined for normal human melanocytes was found to be $0.75 \mathrm{mmol} / \mathrm{L}$ [22], which is higher than the value of this parameter established for COLO 829 melanoma cells, $0.51 \mathrm{mmol} / \mathrm{L}$. The obtained results indicate the higher sensitivity of melanoma cells than normal melanocytes to lomefloxacin treatment. Baharara et al. [35] demonstrated that dacarbazine in a concentration of $8.0 \mathrm{mmol} / \mathrm{L}$ caused a $50 \%$ decrease in the viability of the B16F10 melanoma cell line after $48 \mathrm{~h}$ of incubation. In our study, about a $50 \%$ decrease in the viability of COLO829 cells was achieved for lomefloxacin at a concentration of $0.5 \mathrm{mmol} / \mathrm{L}\left(\mathrm{IC}_{50}\right)$ and $24 \mathrm{~h}$ of incubation, which indicates that lomefloxacin is more cytotoxic towards melanoma cells than dacarbazine is. 
The overproduction of ROS is a well-known mediator in the signal transduction of apoptosis. Increased levels of ROS can induce oxidative stress, a loss of cell function, and finally lead to cell death, that is, apoptosis. It can also induce lipid peroxidation and the cross-linking of thiol groups in proteins [36]. Moreover, tumors can be sensitized to chemotherapy and other antitumor treatment by disabling antioxidant defenses (nicotinamide adenine dinucleotide phosphate (NADPH) and GSH) through metabolic inhibition. Hence, strategies aimed at altering redox signaling in tumor cells and intended to disable key antioxidant systems in the presence of ROS inducers might represent promising new anticancer treatments [23]. The present study was carried out to examine whether lomefloxacin could induce ROS overproduction in COLO829 melanoma cells. The obtained results demonstrate that lomefloxacin induces oxidative stress in cells. Elevated levels of intracellular ROS were observed, especially when the COLO829 cells were exposed to the analyzed drug in the highest concentration, i.e., $1.0 \mathrm{mmol} / \mathrm{L}$. The percentage of ROS increased to $237 \%$ compared to the control (Figure 3), which indicates that the observed cytotoxic effect of lomefloxacin towards COLO829 cells may be associated with increased levels of ROS production.

The intracellular redox status is a precise balance between the oxidative stress and endogenous thiol buffers present in the cells. When unbalanced, it could trigger cellular events downstream such as alterations in mitochondrial function and cell signaling pathways, which lead to apoptotic cell death [17]. Many anticancer drugs can induce apoptosis by disrupting the redox balance. Since GSH, the most abundant cellular thiol and the major determinant of the cellular redox equilibrium, has been shown to be an important factor in apoptosis [37], in the present study, we examined whether the cytotoxic response of lomefloxacin towards COLO829 cells might be associated with the depletion of intracellular GSH levels. The fluorescence image cytometer analysis revealed that lomefloxacin increases the percentages of cells with low GSH levels (Figure 4). The six-fold increase in the percentage of cells with reduced GSH levels was stated for the drug at a concentration of $0.1 \mathrm{mmol} / \mathrm{L}$ and $48 \mathrm{~h}$ incubation time. At higher drug concentrations $(1.0 \mathrm{mmol} / \mathrm{L})$, lomefloxacin caused a significant increase in the percentages of PI-positive (dead) cells, wherein a large number of cells with low vitality lost their plasma membrane integrity. Mirkovic et al. [38] have demonstrated that resistance to radiation-induced apoptosis in a mouse lymphoma cell line was reversed by depleting the cellular thiol levels. Moreover, the depletion of GSH rendered the cells more sensitive to apoptotic agents [39]. On the other hand, elevated GSH levels may decrease apoptosis either by facilitating DNA repair [40] or by buffering the drug-induced oxidative stress [41]. These findings suggest that lomefloxacin may trigger apoptosis in COLO829 cells by depleting the intracellular thiol levels.

The ability of lomefloxacin to induce apoptosis was further confirmed by cell cycle and DNA fragmentation analysis in COLO829 cells. Cell cycle changes have been reported as an important marker that confirms apoptosis [42]. The analyzed drug caused both S- and $\mathrm{G}_{2} / \mathrm{M}$-phase cycle arrest in COLO829 cells (Figure 5), suggesting a mechanism related to topoisomerase II inhibition. Moreover, as evidenced by the image cytometry analysis of DNA fragmentation, lomefloxacin was found to induce oligonucleosomal DNA fragmentation, confirming the induction of apoptosis in COLO829 melanoma cells (Figure 6). The demonstrated increase in ROS generation in COLO829 cells after lomefloxacin treatment may enhance the ability of the analyzed drug to induce this key event of apoptosis. The four-fold and six-fold increases in the percentages of cells with fragmented DNA was observed when the cells were exposed to lomefloxacin in concentrations of $0.1 \mathrm{mmol} / \mathrm{L}$ and 1.0 $\mathrm{mmol} / \mathrm{L}$ for $48 \mathrm{~h}$. These findings are in agreement with the data demonstrated by Perruca et al. [34], wherein lomefloxacin in lower concentrations induced S- and $\mathrm{G}_{2} / \mathrm{M}$-phase cycle arrest in A431 or HeLaS3 cells, whereas, in the case of higher drug concentrations, the accumulation of cells in the sub- $\mathrm{G}_{1}-$ phase was stated. Yadav et al. [29] showed the ability of another fluoroquinolone derivative, ciprofloxacin, to induce S-phase arrest as well as DNA fragmentation in human pancreatic cancer cells. In contrast, Kloskowski et al. [43] demonstrated that, in cases of human non-small lung cancer cells, ciprofloxacin caused cell cycle arrest at the $\mathrm{G}_{2} / \mathrm{M}$ checkpoint. The differences in the mechanistic action of the fluoroquinolone derivative could be attributed to the difference in the origin of the cell type. 
Moreover, it was stated that different molecular pathways can be activated by various fluoroquinolone derivatives in the same cell line [44].

There is no data focusing on the effects of fluoroquinolones on human melanoma cell lines. It is assumed that fluoroquinolones inhibit bacterial type II topoisomerase (gyrase DNA); however they can also affect the viability of certain eukaryotic cells $[19,20,22,23,28,29]$. It is hypothesized that these effects may occur possibly via the unselective inhibition of mitochondrial DNA synthesis with subsequent mitochondrial injury [45]. Thus, topoisomerase inhibitors may induce the selective loss of mitochondrial DNA, finally leading to disorders in the respiratory chain and the depletion of intracellular adenosine triphosphate (ATP) stores. Energy depletion favours apoptosis via the induction of cell cycle arrest in the S-phase and/or $\mathrm{G}_{2} / \mathrm{M}$ phase. Therefore, we investigated mitochondria-dependent events during apoptosis in human melanoma cells such as the breakdown of mitochondrial membrane potential.

Apoptosis may be initiated by the stimulation of death receptors located on the cell surface or through an intrinsic pathway involving the release of apoptotic signals from mitochondria [46]. In the present study, we have demonstrated for the first time that lomefloxacin induces apoptosis in COLO829 melanoma cells as a result of mitochondrial membrane breakdown (Figures 7 and 8). An almost three-fold increase in the percentage of depolarized cells (results from JC-1 staining) was observed for the drug in a concentration of $1.0 \mathrm{mmol} / \mathrm{L}$ and $24 \mathrm{~h}$ of incubation. This phenomenon may be explained by the fact that the disruption of mitochondrial transmembrane potential is an early hallmark in the apoptosis pathway. Moreover, it is possible that lomefloxacin may trigger apoptosis via both intrinsic and extrinsic pathways. After the incubation of the cells with lomefloxacin up to 48 and $72 \mathrm{~h}$, an increase in the percentages of depolarized cells was not observed. Simultaneously, the percentage of late-apoptotic COLO829 cells (results from DAPI-staining) increased, reaching the maximum lomefloxacin concentration $(1.0 \mathrm{mmol} / \mathrm{L})$ and $72 \mathrm{~h}$ of incubation time (an increase of $40 \%$ ) (Figures 7 and 8 ).

The obtained data suggest that both the intrinsic pathway, initiated at the mitochondria, and the extrinsic pathway, initiated by binding of specific ligands generated through ROS overproduction and DNA damage, may be involved in lomefloxacin-induced apoptosis in COLO829 melanoma cells (Figure 9). Similar conclusions for human pancreatic cancer cells were drown by Yadav et al. [29], wherein ciprofloxacin induced extrinsic as well as intrinsic mitochondrial apoptotic pathways.

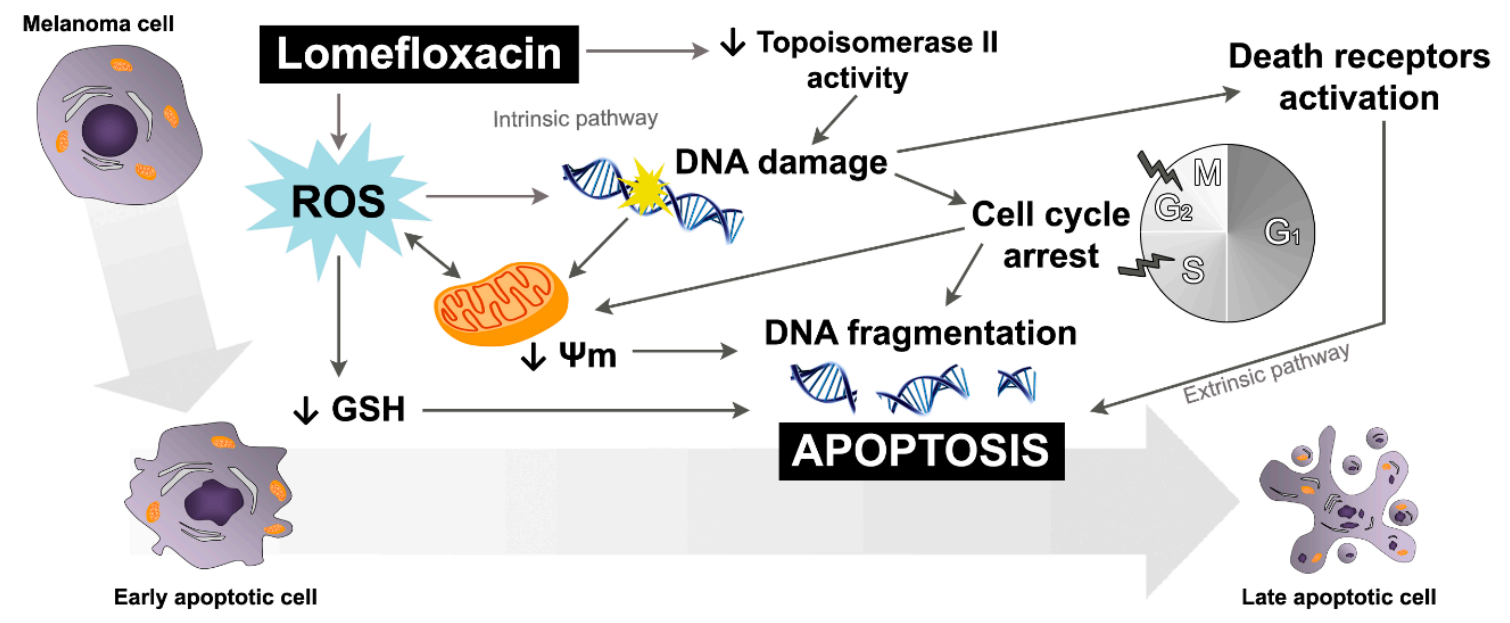

Figure 9. Schematic diagram showing the potential mechanism underlying apoptosis induction in COLO829 melanoma cells by lomefloxacin; $\Psi \mathrm{m}$-mitochondrial transmembrane potential.

One has to take into consideration that the lomefloxacin concentrations found to have cytotoxic and pro-apoptotic effects on COLO829 cells are about 10-fold higher than the concentrations normally 
observed in clinical trials after two po doses of $800 \mathrm{mg}$ [47]. However, the concentrations of lomefloxacin in the targeted tissues may be significantly higher than the concentrations observed in the serum. In other studies describing the effect of ciprofloxacin on human androgen independent prostate carcinoma PC3 cells [48], the colon carcinoma cell lines CC-531, SW-403, and HT-29 [27], as well as the pancreatic cancer cell lines MIA PaCa-2 and Panc-1 [29], the drug was used even in concentrations of $400 \mu \mathrm{g} / \mathrm{mL}$ (above $1.0 \mathrm{mmol} / \mathrm{L}$ ). In all the mentioned studies, significant decreases in cell viability and the induction of apoptosis were shown for ciprofloxacin concentrations higher than $200 \mu \mathrm{g} / \mathrm{mL}$ (about $0.5 \mathrm{mmol} / \mathrm{L}$ ). In our study, significant changes in the analyzed parameters were observed for lomefloxacin concentrations lower than $0.5 \mathrm{mmol} / \mathrm{L}$, especially when COLO829 cells were exposed to the drug for $48 \mathrm{~h}$. Moreover, we have previously demonstrated that lomefloxacin forms complexes with melanin, which may lead to the accumulation of this drug in melanin reach tissues [22]. The obtained results showed that the absolute amount of a drug bound to melanin (expressed as $\mu \mathrm{mol} / \mathrm{mg}$ ) increases when the initial drug concentration rises and the incubation time is prolonged. The performed Scatchard plot analysis of drug-melanin binding has shown that at least two classes of independent binding sites participate in the lomefloxacin-melanin complex formation: strong binding sites with the association constant $\mathrm{K}_{1} \sim 10^{5} \mathrm{M}^{-1}$ and weak binding sites with the association constant $\mathrm{K}_{2} \sim 10^{2} \mathrm{M}^{-1}$. The total number of binding sites $\left(\mathrm{n}_{1}+\mathrm{n}_{2}\right)$ was $0.92 \mu$ mol lomefloxacin per $1 \mathrm{mg}$ melanin. The affinity and capacity for the binding of lomefloxacin to melanin are similar to those of chloroquine, which is well known for its high affinity for melanin $[49,50]$. Thus, it is possible that lomefloxacin concentrations in COLO829 cells may be significantly higher than those in serum, and, therefore, the cytotoxic response, as well as the induction of apoptosis in the presence of this drug, could be observed in vivo.

\section{Materials and Methods}

\subsection{Chemicals}

Lomefloxacin hydrochloride was purchased from Sigma-Aldrich Inc. (St. Louis, MI, USA). Growth medium RPMI 1640, amphotericin B, penicillin, streptomycin, fetal bovine serum, and trypsin/EDTA (ethylenediaminetetraacetic acid) were obtained from Cytogen (Srebrna, Poland). Cell Proliferation Reagent WST-1 was purchased from Roche GmbH (Mannheim, Germany). Solutions $3(1 \mu \mathrm{g} / \mathrm{mL}$ DAPI, $0.1 \%$ triton X-100 in phosphate-buffered saline (PBS)), 7 (200 $\mu \mathrm{g} / \mathrm{mL}$ JC-1), 8 (1 $\mu \mathrm{g} / \mathrm{mL}$ DAPI in $\mathrm{PBS})$, and 5 (VB- $48^{\mathrm{TM}}$, propidium iodide-PI, acridine orange-AO), NC-Slide A8, and Via-1-Cassette (AO and DAPI fluorophores) were obtained from ChemoMetec (Allerod, Denmark). The remaining chemicals were produced by POCH S.A. (Gliwice, Poland).

\subsection{COLO829 Melanoma Cell Culture}

The human melanotic melanoma cell line, COLO829, was obtained from the American Type Culture Collection (ATCC) (CRL-1974, Manassas, VA, USA). The cells were cultured in Roswell Park Memorial Institute medium (RPMI) 1640 medium (with L-glutamine), supplemented with $10 \%$ fetal bovine serum, penicillin $(10,000 \mathrm{U} / \mathrm{mL})$, streptomycin $(10 \mathrm{mg} / \mathrm{mL})$, and amphotericin B $(0.25 \mathrm{mg} / \mathrm{mL})$, at $37^{\circ} \mathrm{C}$ in $5 \% \mathrm{CO}_{2}$. All the experiments were performed using the cells in passages 8 to 11 .

\subsection{Cell Viability Assay}

The viability of COLO829 melanoma cells was evaluated by the WST-1 (4-[3-(4-iodophenyl)2-(4-nitrophenyl)-2H-5-tetrazolio]-1,3-benzene disulphonate) colorimetric assay. The rate of WST-1 cleavage by mitochondrial dehydrogenases correlates with the number of viable cells. In brief, 2500 cells per well were placed in a 96-well microplate in a supplemented RPMI 1640 growth medium and incubated at $37{ }^{\circ} \mathrm{C}$ and $5 \% \mathrm{CO}_{2}$ for $24 \mathrm{~h}$. After incubation, the medium was removed, and the cells were treated with lomefloxacin solutions in concentrations ranging from $0.0001 \mathrm{mmol} / \mathrm{L}$ to $1.0 \mathrm{mmol} / \mathrm{L}$. After 21,45 , or $69 \mathrm{~h}$ of incubation, $10 \mu \mathrm{L}$ of WST-1 solution was added to $100 \mu \mathrm{L}$ of culture medium in each well, and the incubation was continued for $3 \mathrm{~h}$. The absorbance of the samples 
was measured at $440 \mathrm{~nm}$ using a reference wavelength at $650 \mathrm{~nm}$, against the controls (the same cells but not treated with lomefloxacin), using a microplate reader Infinite 200 Pro (Tecan, Männedorf, Switzerland). The controls were normalized to $100 \%$ for each assay, and the treatments were expressed as a percentage of the controls.

\subsection{Cell Morphology Assessment}

In order to investigate the effect of lomefloxacin on cell morphology, the COLO829 cells were seeded in T-25 flasks $\left(1 \times 10^{6}\right.$ cells/flask $)$ in RPMI 1640 supplemented medium. Treatment with lomefloxacin at a concentration of $1.0 \mathrm{mmol} / \mathrm{L}$ began $24 \mathrm{~h}$ after seeding. After 24,48 , and $72 \mathrm{~h}$, the cells were examined under alight inverted microscope from NIKON TS100F (Tokyo, Japan).

\section{5. $\mathrm{H}_{2}$ DCFDA Cellular ROS Detection Assay}

The oxidation of 2,7-dichlorodihydrofluorescein diacetate $\left(\mathrm{H}_{2} \mathrm{DCFDA}\right)$ into 2,7-dichlorofluorescein (DCF) was used to assess the ROS generation in COLO829 melanoma cells after lomefloxacin treatment. In brief, 2500 cells per well were placed in a 96-well dark microplate in a supplemented RPMI 1640 growth medium and incubated at $37^{\circ} \mathrm{C}$ and $5 \% \mathrm{CO}_{2}$ for $24 \mathrm{~h}$. After incubation, the medium was removed and the cells were treated with lomefloxacin solutions ranging from $0.1 \mathrm{mmol} / \mathrm{L}$ to $1.0 \mathrm{mmol} / \mathrm{L}$. After $24 \mathrm{~h}$ of treatment, the medium was removed and the cells were incubated with $10 \mu \mathrm{M}$ $\mathrm{H}_{2}$ DCFDA for $30 \mathrm{~min}$ at $37^{\circ} \mathrm{C}$ and washed twice with PBS to remove excess dye. The fluorescence was read at wavelengths of $485 \mathrm{~nm}$ of excitation and $530 \mathrm{~nm}$ of emission using a microplate reader Infinite 200 Pro (Tecan, Switzerland). The obtained results, normalized to a number of living cells, were finally expressed as a percentage of the controls.

\subsection{Vitality Assay-Assessment of the Level of Cellular Reduced Glutathione (GSH)}

The analysis of the level of cellular thiols in COLO829 cells was performed by the use of the fluorescence image cytometer from NucleoCounter NC-3000 (Allerod, Denmark). The COLO829 cells were seeded in T-75 flasks at a density of $2 \times 10^{6}$ cells per flask. The treatment with lomefloxacin in concentrations $0.1 \mathrm{mmol} / \mathrm{L}$ and $1.0 \mathrm{mmol} / \mathrm{L}$ began $24 \mathrm{~h}$ after seeding. After 24 or $48 \mathrm{~h}$ of incubation, the cells were harvested by trypsinization, loaded into Via-1-Casette, and counted using a NucleoCounter NC-3000 image cytometer. $1.0 \times 10^{6}$ cells were suspended in $1.0 \mathrm{~mL}$ of culture medium, and one volume $(10 \mu \mathrm{L})$ of Solution 5 (which contains AO that stains all cells, PI that stains dead cells only, and VB-28 ${ }^{\mathrm{TM}}$ that stains viable cells in an intensity-dependent manner to the level of thiols) was added into 19 volumes $(190 \mu \mathrm{L})$ of the cell suspension. The stained cells were loaded into an NC-Slide A8 and measured using the Vitality assay protocol in the NucleoCounter NC-3000 image cytometer. The obtained histograms were used to demarcate the percentages of PI negative cells with low vitality (low level of cellular thiols), PI negative cells with high vitality (healthy cells), and PI positive cells (dead cells).

\subsection{Fixed Cell Cycle-DAPI/DNA Fragmentation Assay}

The cell cycle and DNA fragmentation analysis of the COLO829 cells was performed by the use of the fluorescence image cytometer from NucleoCounter NC-3000 (Denmark). The COLO829 cells were seeded in T-75 flasks at a density of $2 \times 10^{6}$ cells per flask. Lomefloxacin treatment in concentrations of $0.1 \mathrm{mmol} / \mathrm{L}$ and $1.0 \mathrm{mmol} / \mathrm{L}$ began $24 \mathrm{~h}$ after seeding. After 24,48 , or $72 \mathrm{~h}$ of incubation, the cells were harvested by trypsinization, loaded into Via-1-Casette, and counted using a NucleoCounter NC-3000 image cytometer. $1.5 \times 10^{6}$ cells were suspended in $0.5 \mathrm{~mL} \mathrm{PBS}$ and fixed with $4.5 \mathrm{~mL}$ of $70 \%$ cold ethanol for at least $2 \mathrm{~h}$ for the analysis of cell cycle distribution and for at least $12 \mathrm{~h}$ for the analysis of DNA fragmentation. Then the ethanol was removed, and the cells were re-suspended in PBS and centrifuged for $5 \mathrm{~min}$ at $500 \times \mathrm{g}$. To each sample, $0.5 \mathrm{~mL}$ of Solution 3 (which, in additon to DAPI, contains $0.1 \%$ triton $\mathrm{X}-100$ to trigger cellular membrane damage) was added, and the cell pellets were incubated for $5 \mathrm{~min}$ at $37^{\circ} \mathrm{C}$. The stained cells were loaded into an NC-Slide A8 and measured using 
Fixed Cell Cycle-DAPI/ DNA fragmentation assay protocols in the NucleoCounter NC-3000 image cytometer. The obtained DNA content histograms were used to demarcate cells in different cell cycle stages or to demarcate apoptotic cells with fragmented DNA having less than one DNA equivalent (so-called Sub-G 1 cells).

\subsection{Mitochondrial Potential Assay}

The mitochondrial transmembrane potential $(\Delta \Psi \mathrm{m})$ was measured by the use of the fluorescence image cytometer NucleoCounter NC-3000 (Denmark). The COLO829 cells were seeded in T-75 flasks at a density of $2 \times 10^{6}$ cells per flask. Lomefloxacin treatment in concentrations of $0.1 \mathrm{mmol} / \mathrm{L}$ and $1.0 \mathrm{mmol} / \mathrm{L}$ began $24 \mathrm{~h}$ after seeding. After 24,48 , or $72 \mathrm{~h}$ of incubation, the cells were harvested by trypsinization, loaded into Via-1-Casette, and counted using a NucleoCounter NC-3000 image cytometer. To $1.0 \times 10^{6}$ cells, $12.5 \mu \mathrm{L}$ of Solution 7 was added, and the cells were incubated for $15 \mathrm{~min}$ at $37^{\circ} \mathrm{C}$. The stained cells were then centrifuged at $400 \times g$ for $5 \mathrm{~min}$ and washed twice with PBS. The cell pellets were re-suspended in $0.25 \mathrm{~mL}$ of Solution 8 (which contains DAPI in PBS) and analyzed immediately using the NC-Slide A8 and Mitochondrial Potential Assay protocol in the NucleoCounter NC-3000 image cytometer. The cellular blue (DAPI), green, and red (JC-1) fluorescence was quantified. The cells with collapsed mitochondrial potential exhibited a decrease in their red/green fluorescence intensity ratio. The obtained scatter-plots and histograms were used to demarcate the percentages of polarized/healthy cells, depolarized/apoptotic cells, and DAPI positive/late apoptotic or necrotic cells.

\subsection{Statistical Analysis}

In all experiments, the mean values of at least three separate experiments $(n=3)$ performed in triplicate \pm standard error of the mean (SEM) were calculated. The results were analyzed statistically using GraphPad Prism 6.01 Software by means of a one-way ANOVA, as well as Dunnett's comparison test. In all cases, the statistical significance was found for $p$-values lower than 0.05 .

\section{Conclusions}

The induction of apoptosis is the main mechanism through which a number of chemotherapeutic agents inhibit cancer cell proliferation. The obtained results provide strong experimental evidence indicating the high cytotoxic activity of lomefloxacin towards COLO829 melanoma cells. The cytotoxic response was found to be mediated by the disruption of redox balance, S- and $\mathrm{G}_{2} / \mathrm{M}$-phase cycle arrest, the breakdown of the mitochondrial membrane potential, and the induction of DNA fragmentation, which trigger drug-induced apoptosis in COLO829 cells (Figure 9). Moreover, when compared with normal human melanocytes, lomefloxacin demonstrates higher cytotoxic activity towards COLO829 melanoma cells than do normal pigmented cells. To the best of our knowledge, this provides, for the first time, an important molecular basis for the pharmacologic effect underlying high lomefloxacin cytotoxic activity towards human melanoma cells and gives a new insight into the therapeutic properties of this drug. The obtained results also support the hypothesis that 6,8-difluoroquinolones may be considered a class of drugs with targeted effects on tumor cells and may constitute a basis for the development of new fluoroquinolone derivatives with potential anticancer activity [34]. With further investigation regarding lomefloxacin preclinical and clinical efficacy, the presented findings could be considered as a potential anti-melanoma therapy.

Acknowledgments: This work was supported by the Medical University of Silesia, grant number KNW-2-007/N/7/K. Author Contributions: Artur Beberok conceived and designed the experiments, performed the experiments, and wrote the paper; Martyna Szlachta and Jakub Rok performed the experiments, Dorota Wrześniok, Zuzanna Rzepka, and Michalina Respondek performed the experiments and analyzed the data; and Ewa Buszman conceived and designed the experiments and wrote the paper.

Conflicts of Interest: The authors declare no conflicts of interest. 


\section{References}

1. Hartman, M.L.; Czyż, M. Pro-survival role of MITF in melanoma. J. Investig. Dermatol. 2015, 135, 352-358. [CrossRef] [PubMed]

2. Chen, H.; Weng, Q.Y.; Fisher, D.E. UV signaling pathways within the skin. J. Investig. Dermatol. 2014, 134, 2080-2085. [CrossRef] [PubMed]

3. Siegel, R.L.; Miller, K.D.; Jemal, A. Cancer statistics, 2016. Cancer J. Clin. 2016, 66, 7-30. [CrossRef] [PubMed]

4. Sandru, A.; Voinea, A.; Panaitescu, E.; Blidaru, A. Survival rates of patients with metastatic malignant melanoma. J. Med. Life 2014, 7, 572-576. [PubMed]

5. Erdei, E.; Torres, S.M. A new understanding in the epidemiology of melanoma. Expert Rev. Anticancer Ther. 2010, 10, 1811-1823. [CrossRef] [PubMed]

6. Shih, V.; Ten Ham, R.M.; Bui, C.T.; Tran, D.N.; Ting, J.; Wilson, L. Targeted therapies compared to dacarbazine for treatment of BRAF(V600E) metastatic melanoma: A cost-effectiveness analysis. J. Skin Cancer 2015. [CrossRef] [PubMed]

7. Wehler, E.; Zhao, Z.; Pinar Bilir, S.; Munakata, J.; Barber, B. Economic burden of toxicities associated with treating metastatic melanoma in eight countries. Eur. J. Health Econ. 2017, 18, 49-58. [CrossRef] [PubMed]

8. Zimmer, L.; Apuri, S.; Eroglu, Z.; Kottschade, L.A.; Forschner, A.; Gutzmer, R.; Schlaak, M.; Heinzerling, L.; Krackhardt, A.M.; Loquai, C.; et al. Ipilimumab alone or in combination with nivolumab after progression on anti-PD-1 therapy in advanced melanoma. Eur. J. Cancer 2017, 75, 47-55. [CrossRef] [PubMed]

9. Johnson, D.B.; Sosman, J.A. Therapeutic advances and treatment options in metastatic melanoma. JAMA Oncol. 2015, 1, 380-386. [CrossRef] [PubMed]

10. Oliphant, C.M.; Green, G.M. Quinolones: A comprehensive review. Am. Fam. Phys. 2002, 65, $455-464$.

11. Hawtin, R.E.; Stockett, D.E.; Byl, J.A. Voreloxin is an anticancer quinolone derivative that intercalates DNA and poisons topoisomerase II. PLoS ONE 2010, 5. [CrossRef] [PubMed]

12. Pommier, Y.; Sun, Y.; Huang, S.N.; Nitiss, J.L. Roles of eukaryotic topoisomerases in transcription, replication and genomic stability. Nat. Rev. Mol. Cell Biol. 2016, 17, 703-721. [CrossRef] [PubMed]

13. Sharma, P.C.; Jain, A.; Jain, S. Fluoroquinolone antibacterials: A review on chemistry, microbiology and therapeutic prospects. Acta Pol. Pharm. 2009, 66, 587-604. [PubMed]

14. Drlica, K. Mechanism of fluoroquinolone action. Curr. Opin. Microbiol. 1999, 2, 504-508. [CrossRef]

15. Cowell, I.G.; Austin, C.A. Mechanism of generation of therapy related leukemia in response to anti-topoisomerase II agents. Int. J. Environ. Res. Public Health. 2012, 9, 2075-2091. [CrossRef] [PubMed]

16. Kathiravan, M.K.; Khilare, M.M.; Nikoomanesh, K.; Chothe, A.S.; Jain, K.S. Topoisomerase as target for antibacterial and anticancer drug discovery. J. Enzym. Inhib. Med. Chem. 2013, 28, 419-435. [CrossRef] [PubMed]

17. Liou, G.Y.; Storz, P. Reactive oxygen species in cancer. Free Radic. Res. 2010, 44, 479-496. [CrossRef] [PubMed]

18. Liu, J.; Wang, Z. Increased oxidative stress as a selective anticancer therapy. Oxid. Med. Cell. Longev. 2015. [CrossRef] [PubMed]

19. Beberok, A.; Wrześniok, D.; Otręba, M.; Buszman, E. Impact of sparfloxacin on melanogenesis and antioxidant defense system in normal human melanocytes HEMa-LP-An in vitro study. Pharmacol. Rep. 2015, 67, 38-43. [CrossRef] [PubMed]

20. Beberok, A.; Wrześniok, D.; Otręba, M.; Miliński, M.; Rok, J.; Buszman, E. Effect of norfloxacin and moxifloxacin on melanin synthesis and antioxidant enzymes activity in normal human melanocytes. Mol. Cell. Biochem. 2015, 401, 107-114. [CrossRef] [PubMed]

21. Talla, V.; Veerareddy, P. Oxidative stress induced by fluoroquinolones on treatment for complicated urinary tract infections in Indian patients. J. Young Pharm. 2011, 3, 304-309. [PubMed]

22. Beberok, A.; Otręba, M.; Wrześniok, D.; Buszman, E. Cytotoxic effect of lomefloxacin in culture of human epidermal melanocytes. Pharmacol. Rep. 2013, 65, 689-699. [CrossRef]

23. Panieri, E.; Santoro, M.M. ROS homeostasis and metabolism: A dangerous liason in cancer cells. Cell Death Dis. 2016, 7. [CrossRef] [PubMed]

24. Lo, J.A.; Fisher, D.E. The melanoma revolution: From UV carcinogenesis to a new era in therapeutics. Science 2014, 346, 945-949. [PubMed]

25. Sissi, C.; Palumbo, M. The quinolone family: From antibacterial to anticancer agents. Curr. Med. Chem. Anticancer Agents 2003, 3, 439-450. [CrossRef] [PubMed] 
26. Jamieson, G.C.; Fox, J.A.; Poi, M.; Strickland, S.A. Molecular and pharmacologic properties of the anticancer quinolone derivative vosaroxin: A new therapeutic agent for acute myeloid leukemia. Drugs 2016, 76, 1245-1255. [CrossRef] [PubMed]

27. Herold, C.; Ocker, M.; Ganslmayer, M.; Gerauer, H.; Hahn, E.G.; Schuppan, D. Ciprofloxacin induces apoptosis and inhibits proliferation of human colorectal carcinoma cells. Br. J. Cancer 2002, 86, 443-448. [CrossRef] [PubMed]

28. Yadav, V.; Sultana, S.; Yadav, J.; Saini, N. Gatifloxacin induces S and G2-phase cell cycle arrest in pancreatic cancer cells via p21/p27/p53. PLoS ONE 2012, 7, e47796. [CrossRef] [PubMed]

29. Yadav, V.; Varshney, P.; Sultana, S.; Yadav, J.; Saini, N. Moxifloxacin and ciprofloxacin induces S-phase arrest and augments apoptotic effect of cisplatin in human pancreatic cancer cells via ERK activation. BMC Cancer 2015. [CrossRef] [PubMed]

30. Suresh, N.; Nagesh, H.N.; Sekhar, K.V.; Kumar, A.; Shirazi, A.N.; Parang, K. Synthesis of novel ciprofloxacin analogues and evaluation of their anti-proliferative effect on human cancer cell lines. Bioorg. Med. Chem. Lett. 2013, 23, 6292-6295. [PubMed]

31. Beberok, A.; Buszman, E.; Otręba, M.; Wrześniok, D. Impact of lomefloxacin on antioxidant enzymes activity in normal melanocytes HEMa-LP. Curr. Issues Pharm. Med. Sci. 2012, 25, 426-429. [CrossRef]

32. De Guidi, G.; Bracchitta, G.; Cataflo, A. Photosensitization reactions of fluoroquinolones and their biological consequences. Photochem. Photobiol. 2011, 87, 1214-1229. [CrossRef] [PubMed]

33. Neumann, N.J.; Blotz, A.; Wasinska-Kempka, G.; Rosenbruch, M.; Lehmann, P.; Ahr, H.J. Evaluation of phototoxic and photoallergic potentials of 13 compounds by different in vitro and in vivo methods. J. Photochem. Photobiol. B Biol. 2005, 79, 25-34. [CrossRef] [PubMed]

34. Perucca, P.; Savio, M.; Cazzalini, O.; Mocchi, R.; Maccario, C.; Sommatis, S.; Ferraro, D.; Pizzala, R.; Pretali, L.; Fasani, E.; et al. Structure-activity relationship and role of oxygen in the potential antitumor activity of fluoroquinolones in human epithelial cancer cells. J. Photochem. Photobiol. B Biol. 2014, 140, 57-68. [CrossRef] [PubMed]

35. Baharara, J.; Amini, E.; Nikdel, N.; Salek-Abdollahi, F. The cytotoxicity of dacarbazine potentiated by sea cucumber saponin in resistant B16F10 melanoma cells through apoptosis induction. Avicenna J. Med. Biotechnol. 2016, 8, 112-119. [PubMed]

36. Shyur, L.F.; Lee, S.H.; Chang, S.T.; Lo, C.P.; Kuo, Y.H.; Wang, S.Y. Taiwanin A inhibits MCF-7 cancer cell acticity through induction of oxidative stress, upregulation of DNA damage checkpoint kinases, and activation of p53 and FasL/Fas signaling pathways. Phytomedicine 2010, 18, 16-24. [CrossRef] [PubMed]

37. Hall, A.G. Review: The role of glutathione in the regulation of apoptosis. Eur. J. Clin. Investig. 1999, 29, 238-245. [CrossRef]

38. Mirkovic, N.; Voehringer, D.W.; Story, M.D.; McConkey, D.J.; McDonnel, T.J.; Meyn, R.E. Resistance to radiation-induced apoptosis in Bcl-2-expressing cells is reversed by depleting cellular thiols. Oncogene 1997, 15, 1461-1470. [CrossRef] [PubMed]

39. Dai, J.; Weinberg, R.S.; Waxman, S.; Jing, Y. Malignant cells can be sensitized to undergo growth inhibition and apoptosis by arsenic trioxide through modulation of the glutathione redox system. Blood 1999, 93, 268-277. [PubMed]

40. Kelland, L.R. New platinum antitumor complexes. Crit. Rev. Oncol. Hematol. 1993, 15, 191-219. [CrossRef]

41. Slater, A.F.; Nobel, C.S.; Maellaro, E.; Bustamante, J.; Kimland, M.; Orrenius, S. Nitrone spin traps and a nitroxide antioxidant inhibit a common pathway of thymocyte apoptosis. Biochem. J. 1995, 306, 771-778. [CrossRef] [PubMed]

42. Pietenpol, J.A.; Stewart, Z.A. Cell cycle checkpoint signaling: Cell cycle arrest versus apoptosis. Toxicology 2002, 181, 475-481. [CrossRef]

43. Kloskowski, T.; Gurtowska, N.; Olkowska, J.; Nowak, J.M.; Adamowicz, J.; Tworkiewicz, J.; Dębski, R.; Grzanka, A.; Drewa, T. Ciprofloxacin is a potential topoisomerase II inhibitor for the treatment of NSCLC. Int. J. Oncol. 2012, 41, 1943-1949. [CrossRef] [PubMed]

44. Blau, H.; Klein, K.; Shalit, I.; Halperin, D.; Fabian, I. Moxifloxacin but not ciprofloxacin or azithromycin selectively inhibits IL-8, IL-6, ERK1/2, JNK and NF-kappa B activation in a cystic fibrosis epithelial cell line. Am. J. Physiol. Lung Cell. Mol. Physiol. 2007, 292, 343-352. [CrossRef] [PubMed] 
45. Lawrence, J.W.; Darkin-Rattray, S.; Xie, F.; Neims, A.H.; Rowe, T.C. 4-quinolones cause a selective loss of mitochondrial DNA from mouse L1210 leukemia cells. J. Cell. Biochem. 1993, 51, 165-174. [CrossRef] [PubMed]

46. Elmore, S. Apoptosis: A review of programmed cell death. Toxicol. Pathol. 2007, 35, 495-516. [CrossRef] [PubMed]

47. Morrison, P.J.; Mant, T.G.; Norman, G.T.; Robinson, J.; Kunka, R.L. Pharmacokinetics and tolerance of lomefloxacin after sequentially increasing oral doses. Antimicrob. Agents Chemother. 1988, 32, 1503-1507. [CrossRef] [PubMed]

48. Aranha, O.; Grignon, R.; Fernandes, N.; McDonnel, T.J.; Wood, D.P., Jr.; Sarkar, F.H. Suppression of human prostate cancer cell growth by ciprofloxacin is associated with cell cycle arrest and apoptosis. Int. J. Oncol. 2003, 22, 787-794. [CrossRef] [PubMed]

49. Larsson, B.S. Interaction between chemicals and melanin. Pigment Cell Res. 1993, 6, 127-133. [CrossRef] [PubMed]

50. Ono, C.; Tanaka, M. Binding characteristics of fluoroquinolones to synthetic levodopa melanin. J. Pharm. Pharmacol. 2003, 55, 1127-1133. [CrossRef] [PubMed]

(C) 2017 by the authors. Licensee MDPI, Basel, Switzerland. This article is an open access article distributed under the terms and conditions of the Creative Commons Attribution (CC BY) license (http:/ / creativecommons.org/licenses/by/4.0/). 